\title{
EXPOSURE CHARACTERIZATION AND POTENTIAL HEALTH IMPACTS OF DOMESTIC FUEL USE IN HOMES IN KHAYELITSHA, WESTERN CAPE
}

\author{
Truter $\mathrm{R}^{1}$, Mbuli S. ${ }^{2}$, Bailie R${ }^{2}$, Danford I', Terblanche APS ${ }^{1}$, Ehrlich R. ${ }^{2}$. \\ 1. Council for Scientific and Industrial Research (CSIR), P O Box 395 Pretoria, 0001. \\ 2. Department of Community Health, University of Cape Town, Medical School, Observatory, Cape Town.
}

\begin{abstract}
The pattern offuel use in Lower socio-economic class homes in the Western Cape differs from that in Gauteng province, in that the use of paraffin and gas predominates. The degree of exposure to gaseons and particulate pollutants as a result of the use of these fuels is not well documented. It is against this background that the study to assess the potential health impacts of air pollution emitted from domestic fuel use in the Western Cape area was conducted. The project collected data on exposure to air pollution in households using parafjin and/or gas and wood in comparison to those using electricity. The study consisted of a pollution monitoring survey and the administration of a questionnaire in each of the homes selected. Pollutants were measured. These were sulphur dioxide, nitrogen dioxide, carbon monoxide and total suspended particulates. Co-located sampling was also performed in one home of each group, measuring indoor and outdoor concentrations simultaneously. The results indicate that the homes using mixed fuels had higher levels of indoor air pollution than those which used mainly electricity, or electricity and gas or parafin. However, these levels were low when compared to coal and wood burning homes in the Gauteng province. This limited exposure assessment study confirms the hypothesis that paraffin (and gas) are cleaner from an air pollution point of view than coal or wood. The respiratory health risks associated with the use of gas and paraffin would therefore be lower than those associated with wood or coal. From an air pollution perspective, the increased use of the former will make a positive contribution. However, promotion of these fuels is constrained by the serious safety concerns around the use of paraffin in lower socio-economic areas.
\end{abstract}

\section{INTRODUCTION}

The World Health Organisation (WHO) has cstimated that up to $90 \%$ of houschold cnergy supplics in sub-Saharan Africa comes from fucls which are low on the encrgy ladder (low cost, high environmental and health impacts). ${ }^{1}$ In South Africa, approximately $60 \%$ of the population depend partially or complctely on coal or wood for cooking and space heating. Paraffin, however, is also widely used in certain area.

Research in urban and rural areas of Gauteng and the Free State has examined air pollution cxposures in communities that use coal and wood as primary encrgy sources. This information has already contributed to the process of developing provisional houschold energy policics aimed at reducing the risk to the health. The pattern of fucl use in lower socioeconomic homes in the Western Cape differs from that in Gauteng, in that the usc of paraffin predominates. The degree of exposure to gascous and particulate pollutants as a result of the use of paraflin is not well documented.

Electricity is widely accepted as the clcaner and safest from of energy, and electrification is cxpected to procecd rapidly in the Western Cape. However, many houscholds in smaller toivns will continue to rely on alternative fucls for the foreseeable future. It is therefore important that in addition to the known fire and poisoning hazards associated with the use of paraflin, the comparative risks to respiratory health of these fuels should be cstablishcd. This information will contribute to the formation of a houschold encrgy policy for South Africa.

The health effects of paraffin are not well known but are being studied. No association has been found between the use of kerosene stoves and lung cancer in Hong Kong although there was some indication of hazards to asthmatics because of sulphur oxide cmissions ${ }^{2}$. It has becn reported by Smith that acute exposure to kerosene smoke over three months produces changes in physiological parametcrs in dogs. Paraffin has 3 times more energy by weight than biofuel and paraffin stoves are more cfficient than typical biomass stoves. The emissions per unit task are lower in kerosene stoves than biomass stoves. ${ }^{2}$

\section{AIMS AND OBJECTIVES}

This project aimed to collect data on exposures to air pollution in households using paraffin and or gas in comparison to those using electricity. The objectives of the project were thus:

- To measure concentrations of sulphur dioxide, nitrogen dioxide, carbon monoxide and volatile organic compounds emitted from fuels in homes using mainly paraffin in an urban area in the Western Cape winter rainfall region and compare them to measurements of pollutants in homes where mainly electricity is used.

- To assess exposures to total suspended particulates (TSP) in a Wcstern Cape community during winter in the various homes and compare the levels among the various groups of fuel users.

- To compare pollutants concentrations with those measured in the coal and paraffin using homes.

\section{METHOD}

The study area was Khayelitsha, Western Cape. The study sample consisted of 72 houscholds. These were stratified into four groups as follows:

Group 1: Formal houses, using electricity almost exclusively. $(\mathrm{n}=19)$

Group 2: Formal houses, using a mix of electricity and paraffin/gas. $(n=28)$

Group 3: Informal houses (shacks), using a mix of electricity and paraffin/gas and wood. (It was expected that very few informal houses were using electricity exclusively.) $(n=18)$ 
The study consisted of air sampling and a questionnaire. Survey respondents werc asked to spccify which fucl was most commonly used for cooking, hcating and lighting. Groups 3 and 4 were randomly sampled from an area of informal housing close to Groups 1 and 2. The survey was undertaken during August 1994. The questionnaire which was administered by pre-traincd intervicwers conversant in Xhosa, English and Afrikaans consisted of questions regarding demographics, fuel usage, and respiratory profile of home occupants. The respondents were selected randomly from a sample as well as a back up sample in case the selected respondents were not available or not willing to participate in the study. The questionnaire survey to determine respiratory health status was conducted at the same time as the pollution survey. Khayelitsha is undergoing a process of rapid electrification of informal dwcllings (shacks).

In the month prior to the survey two adjacent arca of shack settlements were identificd for inclusion in the study. Houses in one of these areas had already been clectrificd (zone 3 ), while houses in the second area were not due for electrification until after the date of completion of the survey (zone 4). The two shack areas were sclected on the basis of their proximity to an arca of formal housing where previous surveys had revealed a pattern of mixed fucl use (as defined above) (zone 2). Each of the zoncs 2, 3 and 4 contained between 200 and 400 houses. The zones were marked off on maps from the City Enginecr's office that identified each housing site with a five digit number. Sampling in each of these zones was systematic with a random starting point. Sample sizes in zones 3 and 4 were 18 houses, and in zone 2 the sample was 26 houses. Where housing sites were unoccupied, or where there was no resident at home after repeated visits, the sites were replaced according to an agrced proccdure.

In zone 3, a number of residents were not using clectricity despite being connected. Houscholds in this area were therefore only included if they used electricity for either lighting, cooking or heating. Houses not using clectricity were replaced according to the agrecd procedurc.

Previous surveys in Khayclitsha have shown that exclusive use of electricity is more or less confined to the relatively wealthier formal housing area. Such arcas are limiled in size, and relatively distant from zoncs 2 to 4 ( $\pm 3 \mathrm{~km})$.

\section{Air Sampling}

Monitoring and sampling of all pollutants were performed inside the cooking areas, whilc TSP was also monitored inside the sleeping areas. Monitoring usually commeneed between 17:00 - 18:00 and lasted for $12-18$ hours on average depending on the battery life and filter loading. In order to gain information on the concentrations of ambient pollutants, co-located measurements were taken in sclected homes in each group.
The monitoring periods varied duc to the fact that the four instruments being used were not placed simultaneously but one after the other four in the homes studied each day and monitoring times were between $12-18$ hours. The removal of the instruments followed the same pattern as the placement, hence the different monitoring periods to include peak exposure times associated with cooking processes in the evenings and carly mornings. Monitors were removed shortly after the morning cooking period $( \pm 08: 00)$. Due to the unavailability of electricity, battery-operated monitors had to be used, limiting the monitoring period. Sulphur dioxide $\left(\mathrm{SO}_{2}\right)$, nitrogen dioxide $\left(\mathrm{NO}_{2}\right)$ and carbon monoxide $(\mathrm{CO})$ were monitored using an electrochemical Exotox Model 75 continuous monitor. The lowest detection limit of the monitor is $0,1 \mathrm{ppm}$. The pollutant data were logged and stored every hour to yicld averaged concentrations of each gas per hour. These monitors have cross-filters which effectively prevent interference from other gases. The monitors were calibrated prior to and after use in accordance with the manufacturers' specifications.

Co-located sampling was conducted in one home per group on the same day as the indoor sampling for that home. The gas monitors were placed in the early afternoon $(15: 00-16: 00)$ in order to cover the evening cooking period and left overnight to monitor the early morning cooking period. They were removed between 08:00 - 9:00 in the morning. No monitoring was undertaken during the day in the homes except on weckends when the monitors were left until the Monday and then removed. Two sets of ambient data in the Group 3 and 4 homes were obtained over the weekend during the day, as access to the home was not possible during the night.

\section{Total Suspended Particulates}

TSP were monitored using a Gill Air model 224-X pump, sampling at $2 / \mathrm{min}$ over a 12 -hour period, starting at 18:00 and including the evenings and early mornings. Cellulose filters were used to collect the particulars. Gravimetric analysis was performed using standard procedures. Quality control/quality assurance procedures included careful inspection of filtcrs for irregularities and re-weighing of a statistically significant sample. A specially equipped weighing room with a temperature and humidity control system was used.

\section{Volatile Organic Compounds (VOCs).}

Total VOCs were sampled using passive $3 \mathrm{M}$ sampling badges over a 1-day pcriod. The samples were analysed by means of gas chromatography. The positioning of the monitors inside the houscholds was standardised as far as possible with respect to their proximity to both the cmission source and the occupants of the home.

\section{Health Risk Assessment}

The health standards which were used for determining the 
potential health risks were the USA National Ambient Air Quality standards uscd by the Environmental Protection Agency and South African Department of Health. It is assumed that cxposure to levcls bclow these standards prove littlc or no threat to health.

\section{RESULTS}

\section{Exposure Assessment}

The health standards for $\mathrm{SO}_{2}$ and $\mathrm{CO}$ were cxceeded in Groups 2 to 4 for bclow $6 \%$ of the total monitoring time. These levels were lower than those recorded in wood, and coal-using houscholds in Gauteng.

The average TSP concentrations measured in cach home group showed that there were no cxcecdances of the standard when averaged out over the full monitoring period, as well as the number of monitoring periods. However, in Groups 2, 3 and 4 single homes were identificd where the 24-hour health standards were cxcecded in $10.7 \%$; $5.6 \%$; and $11.8 \%$ of measurements respectivcly.

\section{Pollution Profiles - Gases (Indoor Concentrations)}

The hourly average results of the gascous pollution are given in figures 1-4. The profile of pollutants for all 4 home groups are given together for case of reference. The relcvant health standards for cach pollutant gas are given on cach graph. The outdoor values are reported later. The measurements were taken between the 7-31 July 1994 and 1-7 August 1994.

\section{Outdoor Pollutant Profiles - Gases}

The results of these measurements indicate that levels of $\mathrm{SO}_{2}$ and $\mathrm{CO}$ were clevated and excecd the ambient standard on certain day's. The results of the ambient measurements are discussed later in this tcxt.

\section{DISCUSSION}

A limitation of this type of study is the difficulty in sampling for long periods due to the lack of clectricity as well as the lack of a large number of gas monitors to measure in the homcs simultancously. For logistical reasons, the project tcam carried out gas and TSP measurements in four homes per day and moved through the four sample groups consecutively. The ideal situation would be to conduct measurements in the same type of homes on the same day at the same time. Similarly, sharing a set of monitors in one home in cach of the four groups each day would be a good option. Howerer, this causes logistical problems such as the distance between homes, requiring more ficld workers, and
Figure 1: Indoor Pollution Sulphur Dioxide $\left(\mathrm{SO}_{2}\right)$ - Hourly values
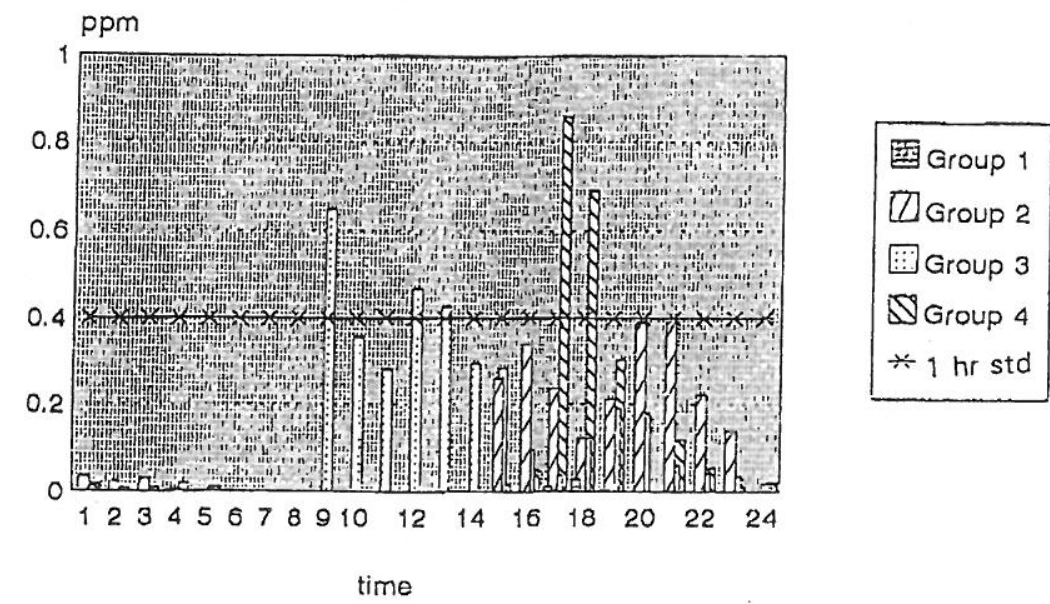

Figure 2: Indoor Pollution Nitrogen Dioxide Measurements For All Groups

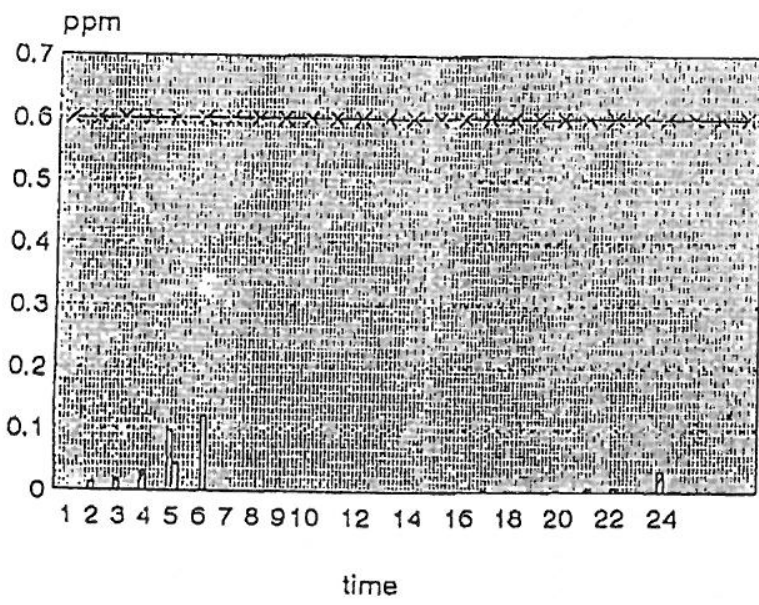

$$
\begin{aligned}
& \text { 圆 Group } 1 \\
& \square \text { Group } 2 \\
& \text { Group } 3 \\
& \$ \text { Group } 4 \\
& \text { * } 1 \text { hr sto }
\end{aligned}
$$

Figure 3: Indoor Pollution Carbon Monoxide Measurements For All Groups - Hourly values

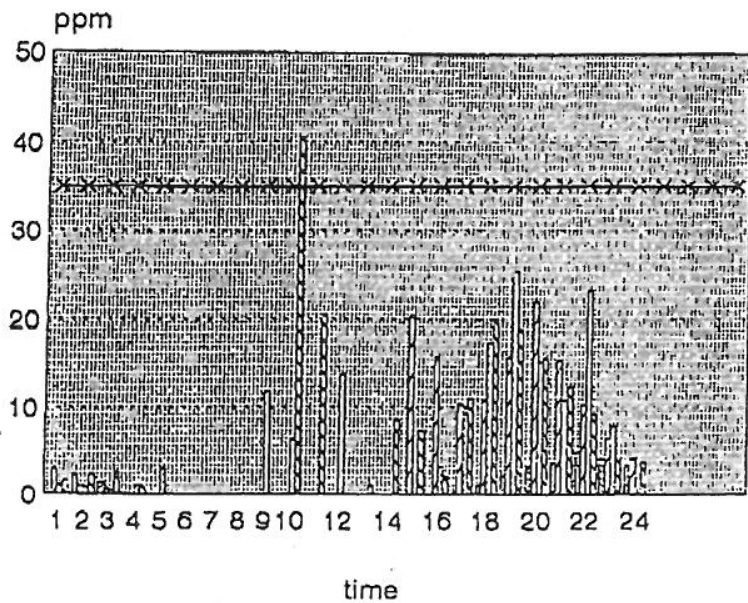


Figure 4: Ambient Sulphur Dioxide Mcasurements In All Groups Hourly values

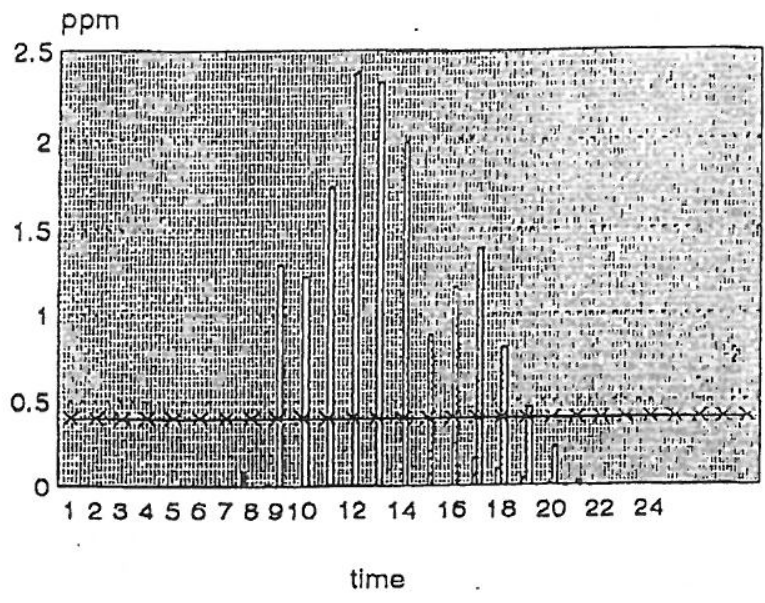

can affect monitoring times. Furthermore, non-clectrificd homes have to rely on battery power whereas the clectrificd homes can run equipment for longer periods. These longer monitoring times in the electrificd homes could slant the results.

\section{Sulphur Dioxide $\left(\mathrm{SO}_{2}\right)$}

$\mathrm{SO}_{2}$ concentrations were clevated during the day and carly evening in Group 3 homes (informal, clectricity mixed fuel use) but Group 4 (informal mixcd fucl use - paraffin and gas as well as wood) recorded the highest single concentrations of $\mathrm{SO}_{2}$ in the evening, peaking at 18:00. The day-time measurcments were obtained over the weekend and have not been deleted from the data set. Thesc elcvated concentrations were possibly from an accumulation of sources due to wind dispersion of geographical topography, but arc most likcly from wood and other sulphur-containing fuels which are burnt outside the shacks in that area.

In the Group 3 arca, the ambient levels were cxcessive and midday concentrations 6 times above the hourly health standard. The highest ambient and indoor peaks did not occur during cooking times as in the other groups but during the day over the weckend. This could be attributed to various sources, mainly wood burning or industrial activities undertaken by the occupants. A small proportion of Group 3 and 4 home occupants used wood for hcating, cooking and lighting. This could possibly be the source of the increased $\mathrm{SO}_{2}$ concentrations. Inspection by the project team did not reveal any nearby refuse burning. These ambient concentrations were recorded over 3 days: 19, 30 and 31 July 1994. The highest ambient average level recorded by the Capc Town City Council for the day was $0.2 \mathrm{ppm}$, measured at Goodwood which is approximately 10 kilometres west of the project site. $\mathrm{SO}_{2}$ poses a health risk to the community from indoor and ambient air pollution in Groups 3 and 4.
Nitrogen Dioxide $\left(\mathrm{NO}_{2}\right)$

Indoor $\mathrm{NO}_{2}$ sources include paraflin and gas. The $\mathrm{NO}_{2}$ concentrations in cach group were low and in no cases was the hourly health standard of 0.60 $\mathrm{ppm}$ excecded ( $\mathrm{DOH}$ guideline). The highest indoor concentration was obtained at 06:00 in the Group 3 homes. The majority of Group 4 homes used paraffin yet no significant $\mathrm{NO}_{2}$ values were measured.

\section{Carbon Monoxide (CO)}

$\mathrm{CO}$ is a product of incomplete combustion. $\mathrm{CO}$ concentrations were elevated in Group 3 and 4 homes, consistent with the mixed fuel use and the small shack-type housing. CO levels were highest in the Group 4 (shacks, no electricity) at 10:00 on a weekend day and then again in Groups 3 and 4 between 18:00 and 19:00 (start-up fires). In the Group 4 area, the highest outdoor concentrations exceeded the hourly health standard at 18:00 on the day of monitoring. This could be due to the lighting of stoves or fires and is a cause for concern.

\section{Total Suspended Particulates}

In an area such as Khayelitsha with its unpaved roads and various fucls used for energy, sources of particulates are numerous. In the complctely electrified group the 24-hour health standard was not excecded. In the mixed fuel groups, the standard for TSP was exceeded in about $10 \%$ of all measurements. The extent of these exceedances and the maximum concentrations recorded were orders of magnitude bclow those documented for Gauteng ${ }^{4-6,8}$ in the predominantly coal and wood using region of Gauteng. In the studies conducted in Gautcng, pollutants exceeded the recommended health standards by between 2-10 times.

\section{KEY FINDINGS}

The pollutant peaks measured in each group were highest in homes where mixed fucls are used, i.c. Groups 3 and 4. Pollutants loads measured reflected the ignition of cooking and heating cquipment in the late afternoons and continued into the early evenings. Heating and cooking sources were also used in the carly mornings as shown in Group 4 . Ambient pollutant levels of sulphur dioxide were high and need further investigation. These elevated peak concentrations may be due to temperature inversions and a large source of fuel burning ncar the pollution monitor. Industrial activity may also have an impact on the levels.

Carbon monoxide hourly mean levels were high in Groups 3 and 4 homes exceeding the hourly health standard indoors (10:00). Ambient concentrations excecded the health standard (18:00) (onc event). Nitrogen dioxide, commonly associatcd with usc of paraffin and gas, was not found above the health standard and was not found in any significant concen- 
trations indoors or outdoors. Volatile organic compounds, also associated with the use of paraffin and gas were not measured in significant values and pose no health risk.

\section{CONCLUSIONS}

Homes in Khayclitsha using mixed fucls in the study arca had higher pollution loads than homcs using only clectricity. However, cumulative or average cxposures to indoor pollution in all groups were rclativcly low and did not pose a significant health risk. When compared with studics of indoor air pollution Gauteng, the average levels of total suspended particulates did not exced any health standards whereas in the Gautcng studics average TSP values were 3 to 12 times higher than the US EPA health standards. Gascous pollutants (sulphur dioxide and carbon monoxide) cxcceded the relevant standards for short periods (cspecially in Groups 3 and 4 where some wood burning was reported) and were lower during the measurement period whereas in the Gauteng study the concentrations werc higher and exceedances longer. Sulphur dioxide outdoor and indoor levels may pose a health risk to occupants in Group 3 and 4 homes. From this winter cross-sectional cxposure assessment study, it is cvident that paraffin (and gas) arc associated with significantly lower levels of gaseous and particulate pollution compared with wood or coal. However, the lcvels occasionally exceeded health standards in the case of $\mathrm{SO}_{2}, \mathrm{CO}$ and TSP in the informal mixed fuel categories (possibly due to uncontrolled wood usage). The fucls arc thercfore not as clean as clectricity, but are prefcrable to coal or wood.

\section{REFERENCES}

1. World Health Organisation, 1991. Indoor air pollution form biomass fucl. WHO/PEP/92.3A, Gencva.

2. Smith, KR, 1987. Biofucls, air pollution and health: A global review. Plenum Prcss, Ncw York.
3. Smith, K R, 1988. Total exposure assessment: Implications for developing countries. Environment, $30: 16$ -20 .

4. Sithole, J S; Turner, C R; Lynch, E; Rorich, R and Annegarn, H, 1991. Air pollution exposures in coalburning residential area of South Africa. Proceedings Nationals Association for Clean Air, Durban.

5. Terblanche, A PS; Opperman, 1; Nel, CME; Reinach, S G; Tosen, G and Cadman, A, 1992. Preliminary results of exposure measurements and health effects of the Vaal Triangle Air Pollution Health Study. S Afr Mcd J, $81: 550-556$.

6. Tcrblanche, AP S; Nel, CME and Opperman, L, 1992. Hcalth and safety aspects of domestic fuels. Report to the Department of Mineral and Energy Affairs. Report No : NE 14/6/30.

7. Von Schirnding, YER; Yach, D and Klein, M, 1991. Acute respiratory infections as an important cause of childhood deaths in South Africa. S Afr Med J, $80: 79$ -82 .

8. Terblanche A P S, 1993. Health Impact of Three Electrification Scenarios for Urban Areas in South Africa. CSIR document. Report to Eskom.

\section{ACKNOWLEDGEMENTS}

The Department of Mincral and Energy Affairs is thanked for their sponsorship of this project. The Energy for Development Research Centre, University of Cape Town for its assistance with the sampling of the study sample. The authors also wish to thank Mrs V. Arkley and A. van Dijk for assisting in the typing and preparation of this report. 